\title{
Ekstraksi, Karakterisasi dan Uji Aktivitas Antioksidan Astaxanthin dari Produk Fermentasi Udang (Cincalok)
}

\author{
Mauludia', Thamrin Usman', Winda Rahmalia1*, Dwi Imam Prayitno2, \\ Siti Nani Nurbaeti ${ }^{3}$
}

\author{
1 Jurusan Kimia, Fakultas Matematika dan Ilmu Pengetahuan Alam, Universitas Tanjungpura \\ 2Jurusan IImu Kelautan, Fakultas Matematika dan IImu Pengetahuan Alam, Universitas Tanjungpura \\ 3Jurusan Farmasi, Fakultas Kedokteran, Universitas Tanjungpura \\ J.. Prof. Dr. H. Hadari Nawawi, Pontianak, 78124 Indonesia \\ Email: winda.rahmalia@chemistry.untan.ac.id
}

\section{Abstract \\ Extraction, Characterization and Antioxidant Activity Test of Astaxanthin from Fermented Shrimp (Cincalok) Products}

Shrimp is one of the aquatic organisms that contain several active compounds, including astaxanthin. Cincalok is one of the fermented shrimp products containing astaxanthin. This study aims to determine the characteristics of astaxanthin extract from cincalok and its antioxidant activity. Extraction of astaxanthin from cincalok was carried out using the reflux method with acetone: cyclohexane $(20: 80 \mathrm{v} / \mathrm{v})$ as a solvent. The identification and characterization of astaxanthin was carried out using thin-layer chromatography (TLC), UV-Vis spectrophotometry, and High-Pressure Liquid Chromatography (HPLC). Meanwhile, the antioxidant activity test was carried out using the 1, 1-diphenyl-2-picrylhydrazyl (DPPH) method in one serial concentration (5; 15; 25 ppm). The results of TLC analysis showed that astaxanthin in cincalok extract has Rf value (0.32). The analysis using a UV-Vis spectrophotometer produced a spectrum with a maximum wavelength of $477 \mathrm{~nm}$, which corresponds to the maximum wavelength of standard astaxanthin. The yield of astaxanthin extract from cincalok in this study was $1.47 \mathrm{mg} / 100 \mathrm{~g}$ wet weight. The chromatogram from the results of UHPLC analysis showed that the retention time of cincalok astaxanthin extract was 6.27 minutes with a purity of 18.03\%. The antioxidant activity of cincalok astaxanthin extract was $568.32 \mathrm{ppm}$

Keywords : Astaxanthin, cincalok, extraction, antioxidant

\begin{abstract}
Abstrak
Udang merupakan salah satu organisme air yang mengandung banyak senyawa aktif, termasuk astaxanthin. Cincalok merupakan salah satu produk hasil fermentasi udang yang mengandung astaxanthin. Penelitian ini bertujuan untuk mengetahui karakteristik ekstrak astaxanthin dari cincalok dan aktivitas antioksidannya. Ekstraksi astaxanthin dari cincalok menggunakan metode refluks dengan pelarut aseton:sikloheksan (20:80 v/v). Identifikasi dan karakterisasi astaxanthin dilakukan dengan menggunakan kromatografi lapis tipis (KLT), spektrofotometri UV-Vis, dan High Pressure Liquid Chromatography (HPLC). Sedangkan uji aktivitas antioksidan dilakukan menggunakan metode 1,1difenil-2-pikrilhidrazil (DPPH) dengan memvariasikan konsentrasi larutan uji, yaitu 5; 15; 25 ppm. Hasil dari penelitian ini melaporkan astaxanthin pada ekstrak cincalok menunjukkan nilai Rf 0,32 pada kromatografi lapis tipis (KLT). Hasil analisis menggunakan spektrofotometer UV-Vis menghasilkan spektra dengan panjang gelombang maksimum $477 \mathrm{~nm}$, yang sesuai dengan panjang gelombang maksimum astaxanthin standar. Randemen ekstrak astaxanthin dari cincalok pada penelitian ini adalah $1,47 \mathrm{mg} / 100 \mathrm{~g}$ berat basah. Kromatogram dari hasil analisis UHPLC menunjukkan waktu retensi ekstrak astaxanthin cincalok yaitu selama 6,27 menit dengan kemurnian sebesar 18,03\%. Aktivitas antioksidan dari ekstrak astaxanthin cincalok diperoleh sebesar 568,32 ppm.
\end{abstract}

Kata kunci : Astaxanthin, cincalok, ekstraksi, antioksidan

*) Corresponding author

www.ejournal2.undip.ac.id/index.php/jkt
Diterima/Received : 02-03-2021, Disetujui/Accepted : 05-09-2021 DOI: https://doi.org/10.14710/jkt.v24i3.10497 


\section{PENDAHULUAN}

Radikal bebas memainkan peran ganda sebagai senyawa beracun dan bermanfaat, karena bisa berbahaya atau bermanfaat bagi tubuh. Radikal bebas diproduksi baik dari metabolisme sel normal in situ atau dari sumber eksternal (polusi, asap rokok, radiasi, obat-obatan). Ketika kelebihan radikal bebas tidak dapat dihancurkan secara bertahap, akumulasi mereka di dalam tubuh menghasilkan fenomena yang disebut stres oksidatif. Proses ini berperan besar dalam perkembangan penyakit kronis dan degeneratif seperti kanker, gangguan autoimun, penuaan, katarak, rheumatoid arthritis, penyakit kardiovaskular dan neurodegeneratif (Pham-Huy et al., 2008). Senyawa yang dapat menghambat terjadinya reaksi pembentukan radikal bebas adalah antioksidan. Antioksidan dapat menyumbangkan satu atau lebih elektron kepada radikal bebas, sehingga dapat menstabilkan radikal bebas tersebut (Lobo et al., 2010).

Astaxanthin (3,3-dihidroksi-ß-karoten-4,4dion) merupakan salah satu ketokarotenoid yang dapat ditemukan dalam ragi merah dan mikroalga (Haematococcus puviallis) (Kidd, 2011). Astaxanthin juga ditemukan dalam organisme air seperti udang, salmon, dan lobster (Silva et al., 2014). Astaxanthin memiliki aktivitas antioksidan yang baik karena memiliki kekuatan 50-100 kali lebih kuat dibandingkan dengan vitamin $\mathrm{E}$ serta dapat membantu aktivitas vitamin $\mathrm{E}$ dan $\mathrm{C}$ sebagai antioksidan (Ekpe et al., 2018; Oh et al., 2020). Astaxanthin mampu menetralkan radikal bebas dengan menerima atau menyumbangkan elektron tanpa menjadi pro-oksidan. Selain itu, astaxanthin juga diketahui mampu menurunkan stres oksidatif pada penderita obesitas, perokok, serta berfungsi sebagai pelindung terhadap peradangan dan penghambat penuaan (Wahyuningsih, 2011; Kim dan Kim, 2018).

Udang, khususnya pada bagian kulit, kaya akan astaxanthin (Ngginak et al., 2013). Armenta et al (2002) melaporkan bahwa kadar astaxanthin dari produk fermentasi kulit udang cenderung lebih tinggi $(1,25 \mu \mathrm{g} / \mathrm{g})$ dibandingkan dengan udang yang tidak difermentasi $(0,96 \mu \mathrm{g} / \mathrm{g})$. Hal ini dikarenakan proses fermentasi yang melibatkan asam laktat dapat melarutkan garam kalsium dalam udang yang mengandung pigmen dalam jumlah besar sehingga meningkatkan kadar astaxanthin saat diekstraksi (Torrisen et al., 1981).

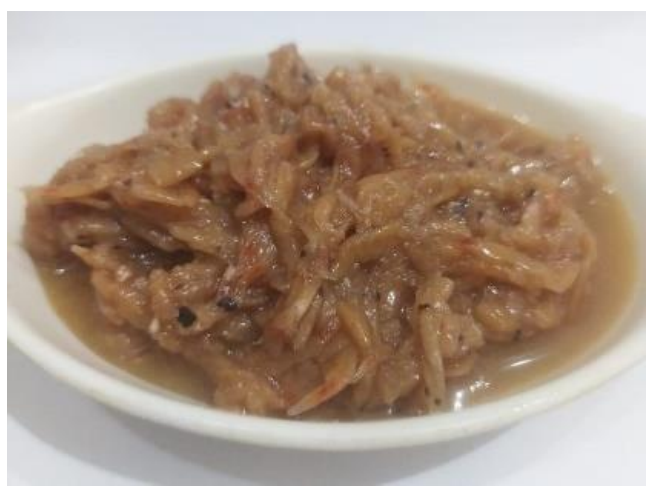

Gambar 1. Cincalok

Cincalok (Gambar 1) merupakan salah satu makanan khas Kalimantan Barat yang dibuat dari fermentasi udang rebon (Acetes japonicus atau Acetes sibogaesibogae). Waktu optimum fermentasi dilaporkan selama 7-8 hari yang ditandai dengan aroma yang khas serta munculnya warna merah muda (Nofiani dan Ardiningsih, 2018). Faradilla (2020), dalam penelitiannya membuktikan kadar karotenoid sebagai astaxanthin dalam cincalok dari udang rebon yang difermentasi selama satu minggu mempunyai kadar yang lebih tinggi (3,29 mg/100 $\mathrm{g}$ berat basah) dibandingkan udang rebon yang tidak difermentasi (2,57 mg/100 g berat basah).

Hingga saat ini, cincalok hanya dikonsumsi oleh masyarakat lokal sebagai lauk-pauk yang belum diketahui manfaat kesehatannya. Sejauh penelusuran kami, penelitian tentang karakteristik serta aktivitas antioksidan astaxanthin yang diekstraksi dari cincalok dengan metode reflux belum pernah dilaporkan. Dalam penelitian ini, dilakukan ekstraksi astaxanthin dari cincalok menggunakan metode refluks dengan campuran aseton dan sikloheksana sebagai pelarut. Identifikasi dan karakterisasi 
astaxanthin dilakukan dengan menggunakan kromatografi lapis tipis (KLT), spektrofotometri UV-Vis, dan kromatografi cair kinerja tinggi (KCKT). Sedangkan uji aktivitas antioksidan dilakukan menggunakan metode 1,1-difenil-2pikrilhidrazil (DPPH).

\section{MATERI DAN METODE}

\section{Preparasi cincalok}

Cincalok yang digunakan dalam penelitian ini dibeli dari salah satu pedagang tradisional di pesisir Kabupaten Mempawah, Kalimantan Barat. Cincalok disaring untuk memisahkan udang dari air, setelah itu cincalok dihaluskan menggunakan blender. Cincalok yang sudah dihaluskan lalu disentrifugasi selama 1 jam. Filtrat dibuang sedangkan residu digunakan untuk proses ekstraksi.

\section{Ekstraksi Astaxanthin dari Cincalok}

Ekstraksi astaxanthin dari cincalok dilakukan dengan memodifikasi metode Senthamil dan Kumaresan (2015). Ekstraksi dilakukan dalam reaktor refluks. Cincalok diambil sebanyak 10 gram dan ditambahkan $20 \mathrm{~mL}$ pelarut aseton:sikloheksana dengan rasio 20:80 (v/v), diaduk secara kontinu menggunakan magnetic stirrer sambil dipanaskan pada temperatur $50^{\circ} \mathrm{C}$ selama 1 jam. Hasil refluks kemudian disentrifugasi selama 1 jam untuk memisahkan filtrat dan residu. Proses ekstraksi terhadap residu dilakukan secara berulang-ulang hingga filtrat yang diperoleh tidak lagi berwarna. Filtrat yang diperoleh selanjutnya divapkan pelarutnya menggunakan gas $\mathrm{N}_{2}$ sehingga diperoleh ekstrak kental. Ekstrak kental cincalok kemudian dipartisi menggunakan dietil eter, akuades dan $\mathrm{NaCl}$ jenuh. Fasa dietil eter diambil dan diuapkan pelarutnya menggunakan gas $\mathrm{N}_{2}$.

\section{Karakterisasi Astaxanthin dari Cincalok}

Kromatografi lapis tipis (KLT) pada penelitian ini menggunakan silika gel $\mathrm{G}_{60} \mathrm{~F}_{254}$ (Merck) dan dielusi dengan pelarut aseton:nheksana 1:4 dan 2:3. Pola pemisahan pigmen diamati berdasarkan noda warna yang terbentuk, kemudian dilakukan perhitungan nilai retardation factor (Rf) pada masingmasing noda dan dibandingkan dengan nilai Rf astaxanthin standar (trans-astaxanthin dari Blakesleatrispora, >97\% KCKT, Sigma Aldrich) (Senthamil dan Kumaresan, 2015; Dalei dan Sahoo, 2015).

Karakterisasi dan identifikasi astaxanthin menggunakan spektrofotometer UV-Vis dilakukan dengan membuat larutan stok terlebih dahulu untuk membuat kurva baku astaxanthin. Larutan stok dibuat dengan melarutkan astaxanthin standar sebanyak $1,25 \mathrm{mg}$ ke dalam pelarut aseton sebanyak 50 $\mathrm{mL}$ hingga diperoleh konsentrasi $25 \mathrm{ppm}$. Astaxanthin standar kemudian ditentukan panjang gelombang maksimumnya dengan mengambil larutan stok sebanyak $0,4 \mathrm{~mL}$ dan dimasukkan ke dalam labu ukur $10 \mathrm{~mL}$ lalu ditambahkan aseton sampai tanda batas, hingga diperoleh konsentrasi 1 ppm. Larutan tersebut kemudian diukur serapannya pada panjang gelombang $400-750 \mathrm{~nm}$.

Selanjutnya dilakukan pengenceran dengan mengambil larutan stok sebanyak 0,$24 ; 0,4 ; 0,56 ; 0,72$; dan $0,88 \mathrm{~mL}$, kemudian dimasukkan ke dalam labu ukur $10 \mathrm{~mL}$ dan ditambahkan aseton sampai tanda batas sehingga diperoleh konsentrasi 0,$6 ; 1 ; 1,4 ; 1,8$; dan 2,2 ppm. Masing-masing larutan disaring lalu diukur serapannya pada panjang gelombang maksimum yang diperoleh sebelumnya. Pengukuran dilakukan masingmasing 3 kali, kemudian data yang diperoleh dibuat dalam bentuk kurva linier yang menunjukkan hubungan linier antara konsentrasi yang diukur dengan absorbansi yang diperoleh.

Ekstrak astaxanthin cincalok diambil secukupnya lalu ditimbang dan ditambahkan $3 \mathrm{~mL}$ aseton, kemudian larutan disaring dengan kertas saring dan diukur serapannya pada panjang gelombang maksimum yang diperoleh sebelumnya. Hasil absorbansi kemudian dikonversi dalam satuan konsentrasi melalui persamaan kurva baku.

Analisis KCKT astaxanthin cincalok dilakukan dengan menggunakan UHPLC (Ultimate 3000-Dionex) yang digabungkan dengan Diode Array Detector (DAD). Astaxanthin dideteksi pada panjang 
gelombang $433 \mathrm{~nm}$ dan dipisahkan dalam UHPLC dengan menggunakan $\mathrm{C}_{18}$ Sunfire (Agilent, panjang $50 \mathrm{~mm}$, diameter dalam 2,1 $\mathrm{mm}$, ukuran partikel 1,8 $\mathrm{mm}$ dengan nomor bagian 9579). Identifikasi astaxanthin menggunakan sistem elusi fase gerak isokratik metanol:air $(95: 5 \mathrm{v} / \mathrm{v})$ dengan laju alir 0,4 $\mathrm{mL} /$ menit dan temperatur $28^{\circ} \mathrm{C}$. Selanjutnya dilakukan analisis dengan prosedur yang sama untuk ekstrak astaxanthin cincalok dan dideteksi pada panjang gelombang maksimum.

\section{Uji aktivitas antioksidan pada ekstrak astaxanthin cincalok}

Larutan stok dari ekstrak astaxanthin cincalok dibuat dalam konsentrasi 1000 ppm dengan menimbang sebanyak 0,05 gram esktrak dan dilarutkan dalam metanol $50 \mathrm{~mL}$, lalu dibuat dalam beberapa konsentrasi yaitu 5, 15 dan 25 ppm. Kemudian ditambahkan 1 $\mathrm{mL}$ larutan DPPH $1 \mathrm{mM}$ dan metanol ke dalam labu ukur $5 \mathrm{~mL}$ sampai tanda batas, lalu dikocok hingga homogen. Larutan blanko dibuat dengan larutan DPPH sebanyak $1 \mathrm{~mL}$ yang ditambahkan metanol ke dalam labu Ukur $5 \mathrm{~mL}$ sampai tanda batas dan dikocok hingga homogen. Selanjutnya larutan diinkubasi pada temperatur $37^{\circ} \mathrm{C}$ selama 30 menit. Kemudian diukur absorbansinya dengan spektrofotometer UV- Vis pada panjang gelombang maksimum dari DPPH yaitu $516 \mathrm{~nm}$. Pengujian dilakukan dengan tiga kali pengulangan. Absorbansi yang diperoleh dihitung \% inhibisinya dan $\mathrm{IC}_{50}$.

Inhibisi $(\%)=\frac{\text { serapan blanko-serapan sampel }}{\text { serapan blanko }} \times 100 \%$

\section{HASIL DAN PEMBAHASAN}

Astaxanthin yang terekstraksi dari cincalok, dalam penelitian ini, terlarut dalam fasa lipid seperti disajikan pada Gambar 2. Hasil ekstraksi diperoleh sebanyak $1,85 \mathrm{~g} / 100 \mathrm{~g}$ berat basah cincalok.

Pelarut aseton:n-heksana 1:4 dipilih sebagai pelarut terbaik berdasarkan pada efektifitas kemampuan pelarut tersebut dalam memisahkan antara senyawa target dengan kelompok senyawa karotenoid lainnya (Senthamil dan Kumaresan, 2015). Hasil separasi pigmen dengan KLT (Gambar 3).
Hasil analisis KLT pada Gambar 3 menunjukkan adanya 6 fraksi, dimana 1 fraksi menunjukkan nilai $\mathrm{Rf}$ yang sama dengan astaxanthin standar. Hal ini membuktikan bahwa cincalok mengandung astaxanthin dengan spot berwarna jingga. Nilai Rf astaxanthin standar dan ekstrak astaxanthin cincalok hasil elusi disajikan pada Tabel 1.

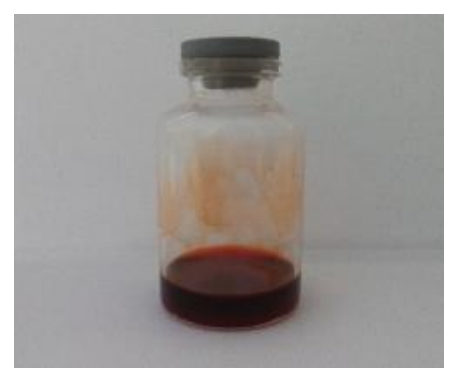

Gambar 2. Ekstrak astaxanthin dari cincalok

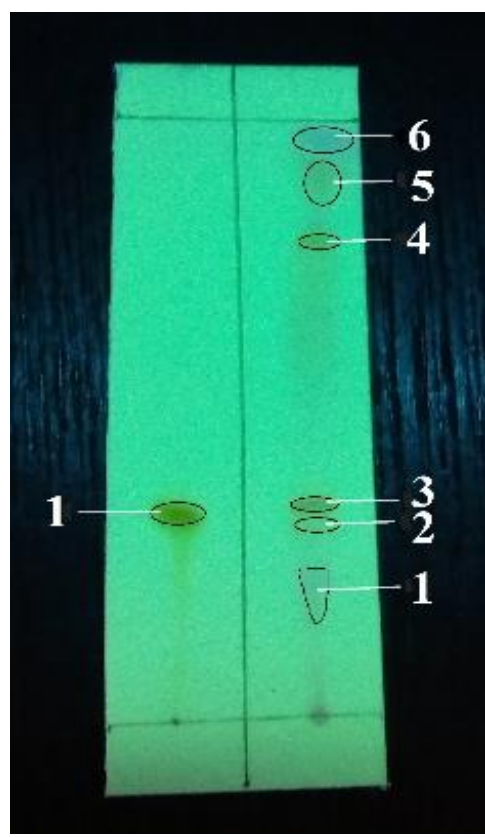

Gambar 3. Kromatogram lapis tipis astaxanthin standar (kiri) dan hasil ekstraksi dari cincalok (kanan)

Analisis menggunakan spektrofotometer UV-Vis dilakukan karena pengerjaan yang cukup mudah, waktu pengerjaan yang singkat, jumlah sampel yang digunakan sedikit, dan data yang dihasilkan lebih valid dengan tingkat ketelitian yang tinggi (Kusnadi dan Devi, 2017). Hasil pengukuran panjang gelombang maksimum larutan astaxanthin 
standar yang diperoleh menggunakan spektrofotometer UV-Vis yaitu $477 \mathrm{~nm}$. Menurut Armenta et al (2009), panjang gelombang maksimum pada pigmen astaxanthin berkisar antara $470-495 \mathrm{~nm}$.

Astaxanthin dapat memberikan serapan pada daerah panjang gelombang cahaya tampak dikarenakan astaxanthin memiliki rantai ganda atau ikatan terkonjugasi yang disebut dengan kromofor dan auksokrom yang dapat menyerap cahaya. Ketika cahaya terserap oleh molekul, semua energi dari cahaya lalu ditransfer oleh molekul tersebut, sehingga daya serap molekul terhadap cahaya meningkat normal dari energi rendah ke keadaan energi yang lebih tinggi (Aesha et al., 2018). Untuk selanjutnya, pengukuran ekstrak astaxanthin cincalok dilakukan pada panjang gelombang $477 \mathrm{~nm}$. Ekstrak astaxanthin cincalok sebanyak $6 \mathrm{mg}$ ditambahkan $3 \mathrm{~mL}$ aseton, kemudian larutan disaring dengan kertas saring dan diukur serapannya. Absorbansi yang diperoleh sebesar 0,553 (Gambar 4).

Absorbansi yang diperoleh kemudian dikonversi dalam satuan konsentrasi melalui persamaan kurva baku, yaitu $y=0,3164 x+$ 0,0313 dengan nilai koefisien korelasi $\left(R^{2}\right)$ sebesar 0,9966 (Gambar 5) yang menunjukkan bahwa semakin tinggi konsentrasi maka semakin tinggi pula absorbansinya. Persamaan ini digunakan untuk menghitung kadar astaxanthin dalam sampel, dimana (y) menyatakan nilai absorbansi dan ( $x$ ) menyatakan kadar astaxanthin dalam sampel. Kadar astaxanthin dari cincalok yang diperoleh pada penelitian ini sebanyak 1,47 $\mathrm{mg} / 100 \mathrm{~g}$ berat basah. Hasil penelitian Faradilla (2020) melaporkan kadar astaxanthin dalam udang rebon yang difermentasi 0,1 , dan 2 minggu dalam $100 \mathrm{gr}$ berat basah berturut-turut yaitu 2,57 mg, 3,29 mg, dan 0,92 mg.

Tabel 1. Nilai Rf pada astaxanthin standar dan ekstrak astaxanthin cincalok dengan pelarut aseton:n-heksana (1:4)

\begin{tabular}{ccc}
\hline Sampel & Spot & Nilai Rf \\
\hline Astaxanthin standar & 1 & 0,31 \\
Ekstrak astaxanthin cincalok & 1 & 0,18 \\
& 2 & 0,28 \\
3 & 0,32 \\
& 4 & 0,76 \\
& 5 & 0,80 \\
6 & 0,86 \\
\hline
\end{tabular}

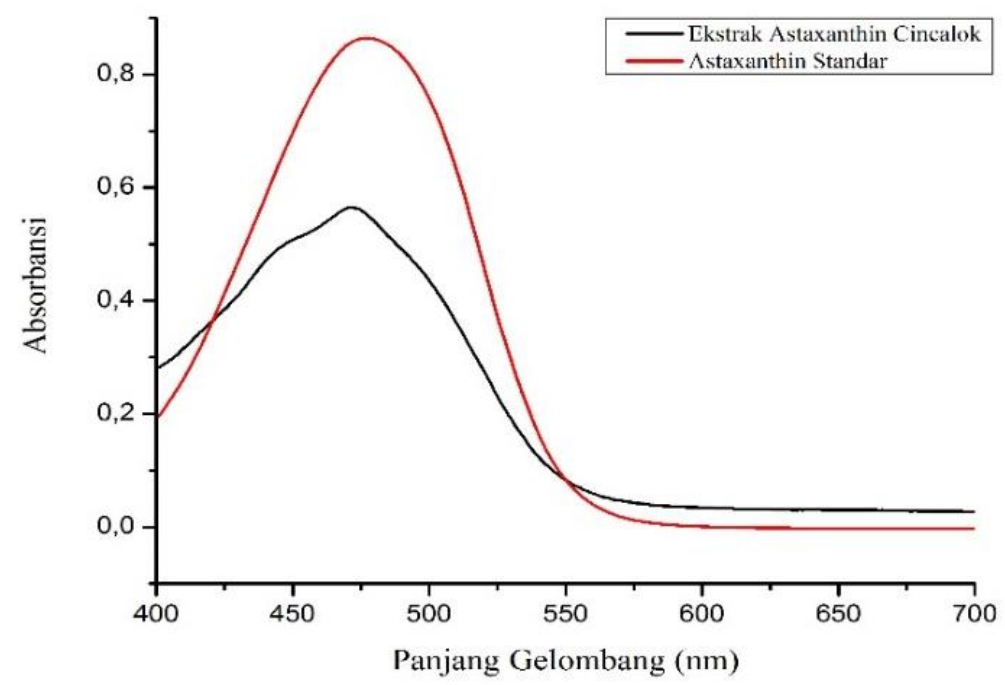

Gambar 4. Spektrum ekstrak astaxanthin cincalok 


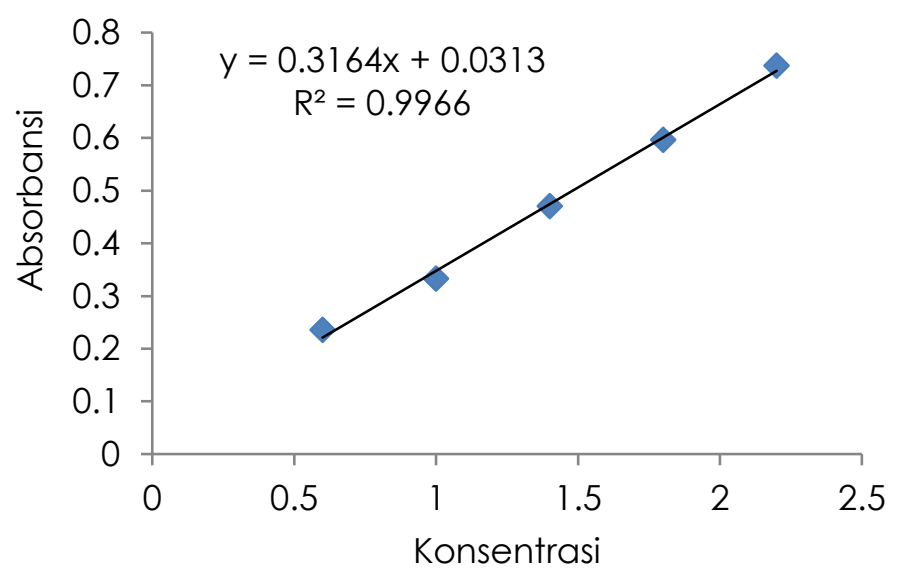

Gambar 5. Penetapan kurva baku dan linieritas astaxanthin standar

Jika dibandingkan dengan hasil penelitian yang dilaporkan oleh Faradilla (2020), kadar astaxanthin dari penelitian ini lebih tinggi dibandingkan kadar astaxanthin cincalok yang difermentasi selama 2 minggu, dan lebih rendah dibandingkan kadar astaxanthin dari udang rebon yang tidak difermentasi dan cincalok yang difermentasi selama 1 minggu. Perbedaan hasil yang diperoleh dapat disebabkan karena jenis dan habitat dari udang tersebut, pengolahan cincalok serta perbedaan waktu fermentasi dan metode ekstraksi. Metode ekstraksi yang digunakan oleh Faradilla (2020) yaitu maserasi dengan cara perendaman menggunakan pelarut aseton, sedangkan ekstraksi dalam penelitian ini menggunakan refluks, yaitu ekstraksi pada temperatur konstan $50^{\circ} \mathrm{C}$ selama 1 jam. Ekstraksi dengan cara pemanasan ini dapat menghasilkan rendemen yang cukup tinggi jika dibandingkan dengan metode maserasi (Nugroho, 2017) sehingga kandungan senyawa yang tersari juga semakin tinggi.

Cincalok yang digunakan dalam penelitian ini merupakan cincalok komersial dengan waktu fermentasi 18 hari. Umumnya proses fermentasi dapat menyebabkan peningkatan gizi dan kualitas pada produk fermentasi tersebut serta dapat meningkatkan kandungan senyawa organik karena bakteri asam laktat yang tumbuh mendegradasi substrat pada bahan baku produk fermentasi. Proses fermentasi asam laktat yang dihasilkan bakteri asam laktat dapat menurunkan $\mathrm{pH}$ pada bahan baku cincalok (Khairina et al.,
2016). Lamanya waktu fermentasi mempengaruhi kadar astaxanthin dalam produk fermentasi cincalok, dimana astaxanthin stabil pada rentang $\mathrm{pH}$ 4-11, sedangkan udang pada umumnya memiliki pH 6 (Rinto, 2018; Azizah et al., 2012).

Penelitian Leliqia et al. (2014) menunjukkan semakin lama waktu fermentasi maka semakin banyak pula konsentrasi asam laktat dan asam asetat yang menyebabkan perubahan $\mathrm{pH}$ semakin rendah pada minuman kombucha. Rendahnya kadar astaxanthin dalam penelitian ini dapat terjadi karena perubahan $\mathrm{pH}$ yang berada pada $\mathrm{pH}$ ambang batas stabilitas astaxanthin $(\mathrm{pH}=4)$ seperti yang dilaporkan oleh Azizah et al. (2012) dan kemungkinan menyebabkan pigmen astaxanthin terdegradasi. Selain itu, kadar air yang masih tercampur juga menyebabkan sampel memiliki kelembapan yang lebih tinggi, sehingga sampel mudah terdegradasi oleh mikroorganisme, tumbuh jamur, dan penguraian oleh enzim. Zahrah et al. (2020) melaporkan bahwa tubuh udang mengandung enzim polifenoloksidase yang dapat mempengaruhi kestabilan astaxanthin dan menyebabkan perubahan warna pada produk fermentasi udang menjadi kehitaman.

Analisis KCKT atau high performance liquid chromatography (HPLC) astaxanthin cincalok dilakukan dengan menggunakan UHPLC (Ultimate 3000-Dionex) yang digabungkan dengan Diode Array Detector (DAD). UHPLC merupakan instrumentasi yang menghasilkan efisiensi yang lebih tinggi dalam 
analisis dibanding metode konvensional KCKT. Efisiensi tersebut berupa penurunan waktu analisis, jumlah sampel dan fase gerak yang diperlukan serta biaya yang lebih murah. Selain itu, keuntungan dari UHPLC dibanding KCKT konvensional yaitu meningkatkan sensitivitas, menghasilkan selektivitas, dan menghasilkan puncak kromatogram yang lebih sempit, tajam, dan tinggi (Annissa et al., 2020).

Astaxanthin dideteksi pada panjang gelombang $430 \mathrm{~nm}$. Pemilihan panjang gelombang untuk menentukan astaxanthin didasarkan pada absorbansi maksimum pada pemindaian UV-Vis. Pelarut yang digunakan untuk melarutkan astaxanthin dalam analisis ini menggunakan pelarut aseton:metanol (1:4 $v / v)$. Metanol memiliki polaritas yang lebih tinggi dibandingkan aseton. Metanol lebih banyak digunakan sebagai pelarut, sehingga bila diukur akan terjadi efek hipsokromik. Efek hipsokromik atau pergeseran biru merupakan terjadinya interaksi pada panjang gelombang yang lebih kecil yang diakibatkan salah satunya oleh bertambahnya kepolaran pelarut. Hal ini dikarenakan kemampuan pelarut metanol mengadakan ikatan hidrogen dengan senyawa dalam keadaan dasar cukup kuat sebelum tereksitasi, sehingga elektron non bonding (n) untuk melakukan eksitasi $n \rightarrow \pi^{*}$ memerlukan energi yang lebih besar, akibatnya panjang gelombang transisi ini akan digeser ke panjang gelombang maksimum yang lebih kecil (Sudarmadji et al., 1997; Suhartati, 2017).

Kromatografi yang digunakan dalam penelitian ini merupakan kromatografi partisi fase terbalik, dimana digunakan fase diam silika gel berupa nonpolar dan fase gerak berupa senyawa yang lebih polar. Fungsi dari fase gerak yaitu melarutkan campuran zat dan membawa komponen yang akan dipisahkan melewati fase diam sehingga memiliki waktu retensi dan selektivitas yang memadai untuk campuran senyawa yang akan dipisahkan (Wulandari, 2011).

Astaxanthin standar terdeteksi pada panjang gelombang maksimum $430 \mathrm{~nm}$. Astaxanthin memiliki ikatan rangkap terkonjugasi pada strukturnya yang berperan terhadap penyerapan cahaya pada kromofor, sehingga dapat terdeteksi pada panjang gelombang di atas $400 \mathrm{~nm}$ yang merupakan cahaya tampak. Selanjutnya dilakukan analisis dengan prosedur yang sama untuk ekstrak astaxanthin cincalok dan dideteksi pada panjang gelombang maksimum $430 \mathrm{~nm}$. Bentuk kromatogram yang dihasilkan dari analisis UHPLC dapat dilihat pada Gambar 6 dan Gambar 7.

Kromatogram dari hasil analisis menunjukkan waktu retensi astaxanthin standar yang ditempun yaitu selama 6,28 menit dengan persentase luas area $80,27 \%$,

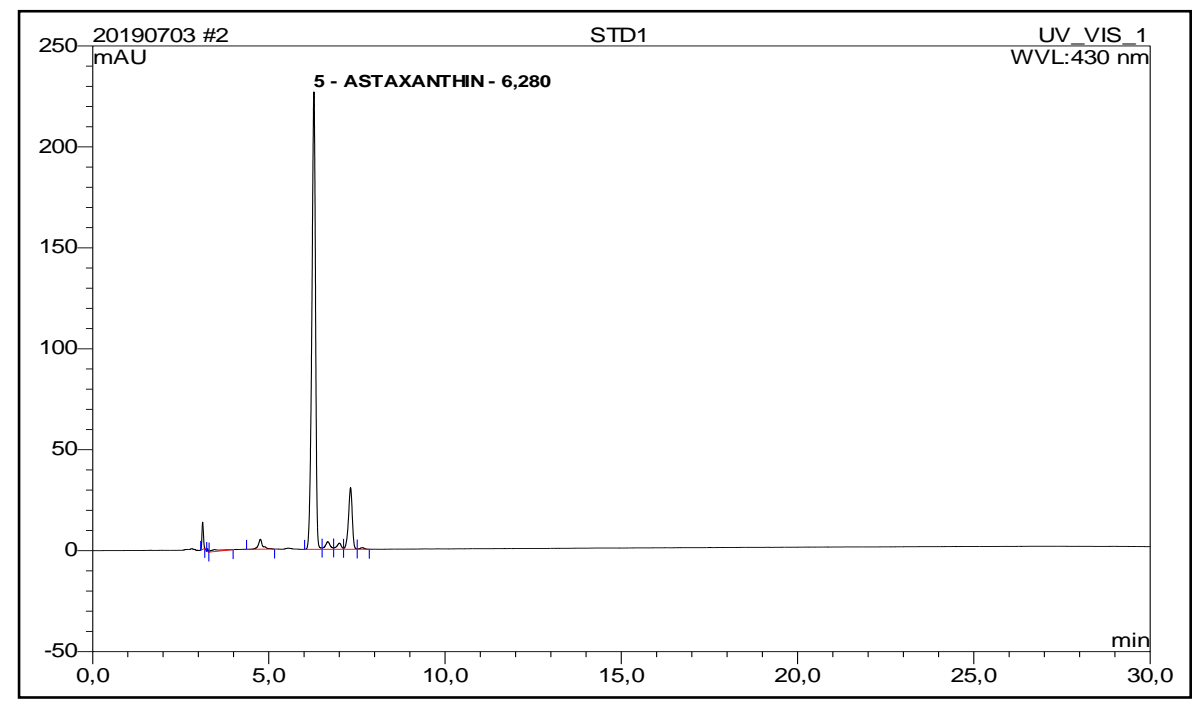

Gambar 6. Kromatogram astaxanthin standar 


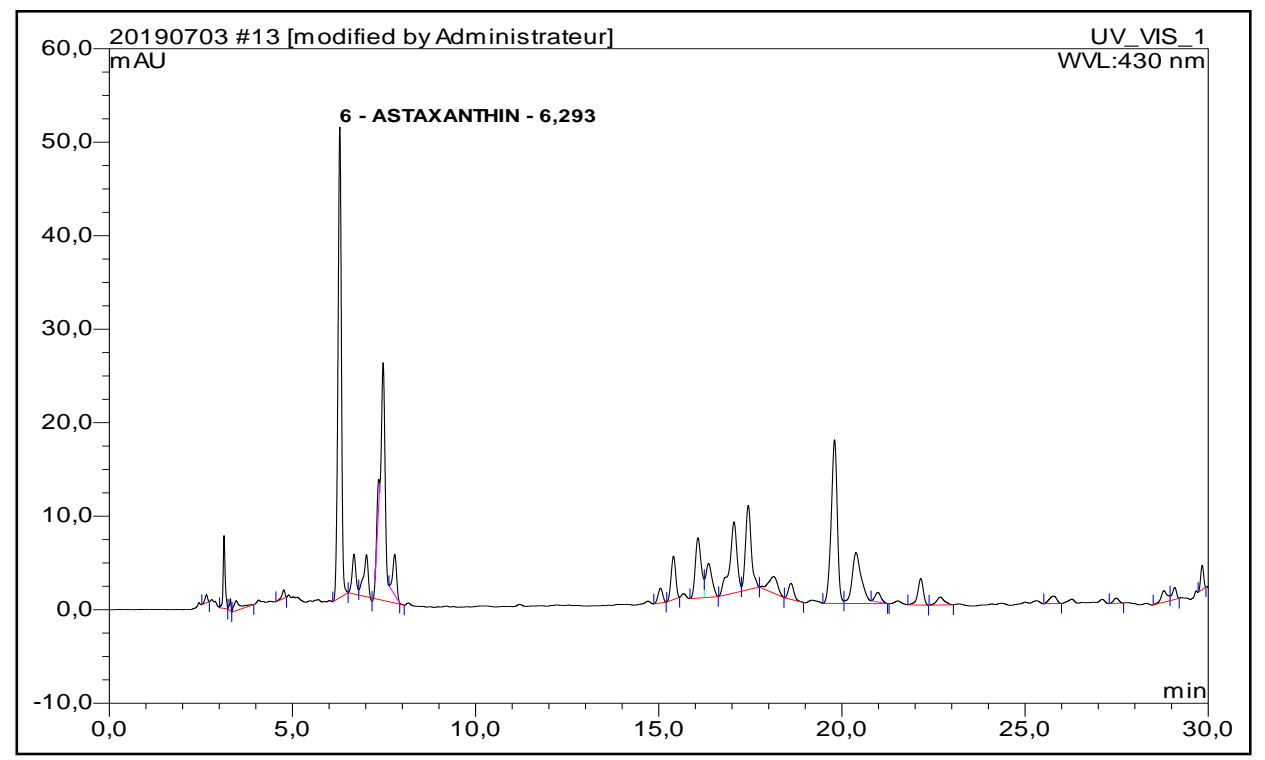

Gambar 7. Kromatogram ekstrak astaxanthin cincalok

mendekati waktu retensi astaxanthin standar. Dari hasil penelitian ini dapat dilihat bahwa cincalok mengandung pigmen transastaxanthin dengan komposisi terbanyak. Berdasarkan persentase luas area puncak, derajat kemurnian trans-astaxanthin dalam ekstrak adalah 18,03\%.

\section{Rendahnya kemurnian astaxanthin yang dihasilkan dalam penelitian ini disebabkan karena sampel masih berupa ekstrak kasar dalam fasa lipid yang masih mengandung asam lemak tak jenuh, omega- 3, dan bentuk ester dari berbagai jenis asam lemak yang berupa metil ester atau dimetil ester (Gastelum et al., 2015; Rodriguez, 2001). Penelitian Hu et al. (2019) melaporkan ekstrak kasar dari cangkang udang yang diekstraksi dengan cara saponifikasi dan dimurnikan dengan kromatografi kolom silika gel menghasilkan peningkatan kemurnian astaxanthin dari $0,34 \%$ menjadi $85,1 \%$. Sehingga untuk mendapatkan kemurnian astaxanthin yang lebih tinggi perlu dilakukan pemurnian lebih lanjut.}

\section{Uji Aktivitas Antioksidan pada Ekstrak Astaxanthin Cincalok}

Penentuan aktivitas antioksidan pada ekstrak cincalok dilakukan dengan uji DPPH (1,1-difenil-2-pikrilhidrazil) menggunakan analisis spektofotometri UV-Vis. DPPH merupakan salah satu radikal nitrogen organik yang stabil berwarna ungu. Selain itu, DPPH dapat larut dalam pelarut polar seperti metanol dan etanol. Adanya senyawa yang bersifat sebagai peredam radikal akan mereduksi radikal DPPH dengan mendonorkan atom hidrogennya membentuk senyawa difenil pikrilhidrazin (non radikal) yang dapat ditandai dengan perubahan warna dari warna ungu radikal DPPH menjadi warna kuning (golongan pikril). DPPH berfungsi menentukan konsentrasi inhibisi (IC $\left.\mathrm{C}_{50}\right)$ yang dinyatakan dalam total antioksidan yang diperlukan untuk meredam 50\% aktivitas radikal DPPH. Semakin kecil nilai $I_{50}$, maka semakin besar potensinya sebagai antioksidan (Molyneux, 2004; Marxen et al., 2007).

Langkah pertama dalam pengujian aktivitas antioksidan dilakukan penentuan panjang gelombang maksimum dan waktu inkubasi optimum pada larutan DPPH. Menurut Marxen et al (2007), panjang gelombang maksimum DPPH berkisar antara 515-520 nm. Dalam penelitian ini, panjang gelombang maksimum DPPH dalam pelarut methanol adalah $516 \mathrm{~nm}$. Waktu inkubasi optimum diperoleh selama 30 menit. Panjang gelombang dan waktu inkubasi optimum inilah yang selanjutnya digunakan dalam pengukuran aktivitas antioksidan pada sampel. 
Aktivitas antioksidan larutan uji ekstrak astaxanthin cincalok dinyatakan dengan persentase penghambatan (\%inhibisi) dan nilai IC 50. Persentase penghambatan (\%inhibisi) adalah kemampuan ekstrak untuk menghambat radikal bebas yang berhubungan dengan konsentrasi ekstrak tersebut. Nilai $\mathrm{IC}_{50}$ adalah penggambaran besarnya konsentrasi efektif pada ekstrak yang dapat menangkap radikal bebas sebanyak 50\%. Hubungan konsentrasi ekstrak astaxanthin cincalok dengan \%inhibisi dapat dilihat pada Gambar 8. Nilai $I_{50}$ ekstrak astaxanthin cincalok dapat dihitung dengan persamaan regresi linier $y=a x+b$, dimana $y$ adalah besarnya persentase inhibisi dengan nilai sebesar 50 dan $\times$ adalah konsentrasi larutan uji yang mampu menghambat $50 \%$ larutan radikal bebas DPPH. Hasil pengujian antioksidan dapat ditunjukkan pada Tabel 2.

Persentase penghambatan (\%inhibisi) ekstrak astaxanthin cincalok terhadap radikal bebas DPPH menunjukkan bahwa semakin tinggi konsentrasi ekstrak, tingkat inhibisinya semakin naik. Hal ini sesuai dengan penelitian yang telah dilakukan Rohimat et al (2014) yang menyatakan bahwa tingkat inhibisi meningkat seiring dengan meningkatnya konsentrasi ekstrak. Nilai $I_{50}$ ekstrak astaxanthin cincalok menunjukkan bahwa ekstrak dapat menghambat aktivitas radikal bebas DPPH sebesar $50 \%$. Semakin kecil nilai IC 50 , maka akan semakin baik aktivitas

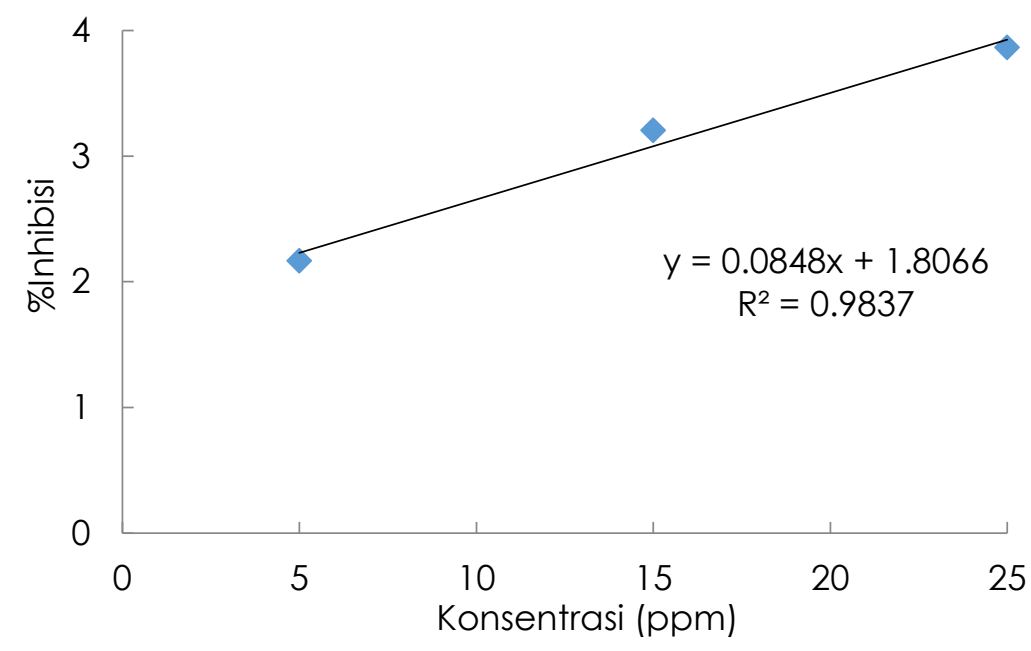

Gambar 8. Kurva peredaman DPPH ekstrak astaxanthin cincalok pada konsentrasi 5; 15; 25 ppm

Tabel 2. Hasil uji aktivitas antioksidan terhadap ekstrak astaxanthin cincalok

\begin{tabular}{|c|c|c|c|c|}
\hline $\begin{array}{l}\text { Konsentrasi } \\
\text { (ppm) }\end{array}$ & $\begin{array}{l}\text { Absorbansi pada panjang } \\
\text { gelombang } 516 \mathrm{~nm}\end{array}$ & $\begin{array}{l}\text { Rata-rata } \\
\text { absorbansi }\end{array}$ & \%Inhibisi & IC50 \\
\hline \multirow{3}{*}{ Blanko } & 1,029 & & & \multirow{12}{*}{568,32} \\
\hline & 1,043 & 1,061 & - & \\
\hline & 1,111 & & & \\
\hline \multirow{3}{*}{5} & 1,017 & & & \\
\hline & 1,050 & 1,038 & 2,168 & \\
\hline & 1,047 & & & \\
\hline \multirow{3}{*}{15} & 1,034 & & & \\
\hline & 0,994 & 1,027 & 3,205 & \\
\hline & 1,052 & & & \\
\hline \multirow{3}{*}{25} & 1,023 & & & \\
\hline & 1,025 & 1,020 & 3,864 & \\
\hline & 1,012 & & & \\
\hline
\end{tabular}


antioksidannya. Namun aktivitas antioksidan ekstrak astaxanthin cincalok pada penelitian ini masih tergolong sangat lemah karena memiliki nilai $I_{50}$ lebih besar dari 200 ppm. Suatu bahan atau suatu senyawa dapat dikatakan sebagai antioksidan kuat apabila memiliki nilai $I_{50}$ kurang dari 200 ppm (Molyneux, 2004).

Aktivitas antioksidan yang rendah pada penelitian ini dapat dipengaruhi oleh kemurnian ekstrak astaxanthin yang relative rendah (18,03\%). Senyawa-senyawa lain yang yang ikut tersari dalam pelarut saat proses ekstraksi diduga bukan merupakan senyawa antioksidan. Gastelum et al (2015) dan Rodriguez (2001) melaporkan ekstrak dari produk sampingan udang dapat berupa minyak yang mengandung asam lemak tak jenuh, omega-3, astaxanthin, dan bentuk ester dari berbagai jenis asam lemak yang berupa metil ester atau dimetil ester.

\section{KESIMPULAN}

Berdasarkan hasil penelitian yang telah dilakukan, maka dapat disimpulkan bahwa cincalok mengandung astaxanthin dalam bentuk trans-astaxanthin yang dapat menyerap cahaya tampak karena memiliki rantai ganda atau ikatan terkonjugasi dan auksokrom, menyebabkan cincalok berwarna merah muda. Kadar astaxanthin dari cincalok yang diperoleh pada penelitian ini sebanyak $1,47 \mathrm{mg} / 100 \mathrm{~g}$ berat basah. Kromatogram dari hasil analisis UHPLC menunjukkan kemurnian trans-astaxanthin yang terlarut dalam fasa lipid hasil ekstraksi adalah 18,03\%. Hasil perhitungan aktivitas antioksidan dari ekstrak astaxanthin cincalok diperoleh $\mathrm{IC}_{50}$ sebesar 568,32 ppm, mengindikasikan bahwa aktivitas antioksidan pada ekstrak astaxanthin cincalok tergolong sangat lemah.

\section{DAFTAR PUSTAKA}

Aesha, M., Indumathu, M. \& Rathu, C. 2018. Extraction and Characterization of Astaxanthin from Prawn Shell Waste. Eurasian Journal of Analytical Chemistry. 13(2):422-428.

Annissa, S., Musfiroh, I. \& Indriati, L. 2020. Perbandingan Metode Analisis Instrumen
HPLC dan UHPLC: Article Review, Farmaka 17(3):189-196. doi: 10.24198/jf.v17i3.21894

Armenta, L.R., Guerrero, L. \& Huerta, S. 2002. Astaxanthin Extraction From Shrimp Waste by Lactic Acid Fermentation and Enzymatic Hidrolysis of the Carotenoprotein Complex. Journal of Food Science 67(3): 1002-1006. doi: 10.1111/j.1365-2621.2002. tb09443.x

Armenta, R.E., Guerrero, S. \& Legarreta. 2009. Stability Studies on Astaxanthin Extracted from Fermented Shrimp Byproducts. Journal of Agricultural and Food Chemistry 57(14):6095-6099. doi: 10.1021/ jf901083d

Azizah, N., Al-Baarri, A. N. \& Mulyani, S. 2012. Pengaruh Lama Fermentasi Terhadap Kadar Alkohol, pH, dan Produksi Gas pada Proses Fermentasi Bioetanol dari Whey dengan Substitusi Kulit Nanas. Jurnal Aplikasi Teknologi Pangan. 1(2):72-77.

Dalei, J. \& Sahoo, D. 2015. Extraction and Characterization of Astaxanthin from the Crustacean Shell Waste Shrimp Processing Industries. International Journal of Pharmaceutical Science and Research. 6(6):2532-2537. doi: 10.13040/IJPSR.0975$8232.6(6) .2532-37$

Ekpe, L., Inaku, K.O., Ekpe, V. \& Contact, L. 2018. Antioxidant effects of astaxanthin in various diseases??? a review. Journal of Molecular Pathophysiology. 7(1):1-6. doi: 10.5455/jmp.20180627120817

Faradilla, A. 2020. Penetapan Kadar Astaxanthin dalam Udang Rebon dan Cincalok, Fakultas Kedokteran, Universitas Tanjungpura, Pontianak (Skripsi).

Gastelum, J.A.N., Machado, D.I.S., Cervantes, J.L., Nunez, J.R.R., Murrieta, M.A.C., Duarte, R.G.S. \& Baypoli, O.N.C. 2015. Astaxanthin and its Esters in Pigmented Oil from Fermented Shrimp by-Products. Journal of Aquatic Food Product Technology. 25(3): 334-343. doi: 10.1080/10498850. 2013.851756

Hu, J., Lu, W., LV, M., Wang, Y., Ding, R. \& Wang, L. 2019. Extraction and Purification of Astaxanthin from Shrimp Shells and the Effects of Different Treatments on its Content. Brasileira de Farmacognosia. 29: 24-29. doi: 10.1016/j.bjp.2018.11.004

Khairina, R., Cahyanto, M.N., Utami, T. \& Rahardjo, S. 2016. Karakteristik Fisikawi, Kimiawi, dan Mikrobiologis Ronto selama 
Penyimpanan. Jurnal Pengolahan Hasil Perikanan Indonesia. 19(3):348-355. doi: 10.17844/jphpi.2016.19.3.348

Kidd. P. 2011. Astaxanthin Cell Membrane Nutrient with Diverse Clinical Benefits and Anti-Aging Potential. Alternative Medicine Review: a Journal of Clinical Therapeutic. 16(4): 355- 362.

Kim, S.H. \& Kim, H. 2018, Inhibitory Effect of Astaxanthin on Oxidative Stress-Induced Mitochondrial Dysfunction-A Mini-Review, Nutrients 10(1137): 1-14. doi: 10.3390/nu10 081137

Leliqia, N.P.E., Susanti, N.M.P. \& Chanjaya, C. 2014. Pengaruh Lama Fermentasi terhadap Aktivitas Antioksidan Minuman Kombucha Lokal di Bali dengan Substrat Produk Gambir. Jurnal Farmasi Udayana, 3(1):116-119.

Lobo, V., Patil, A. \& Chandra, N. 2010. Free Radicals, Antioxidants and Functional Foods on Human Health, Pharmacognosy Reviews. 4(8):118-126. doi: 10.4103/09737847.70902

Marxen, K., Vanselow, K. H., Lippemeier, S. \& Hintze, R. 2007. Determination of DPPH Radical Oxidation Caused by Methanolic Extracts of Some Microalgal Species by Linear Regression Analysis of Spectrophotometric Measurements, Sensors. 7:20802095. doi: 10.3390/s7102080

Molyneux, P. 2004. The Use of the Stable Free Radical Diphenylpicrylhydrazyl (DPPH) for Estimating Antioxidant Activity. Journal of Science Technology. 26(2):211-219.

Ngginak, J., Semangun, H., Mangimbulude, J. C. \& RondonuwU, F.S. 2013. Komponen Senyawa Aktif pada Udang serta Aplikasinya dalam Pangan, Jurnal Sains Medika. 5(2): 132-133. doi: 10.26532/sains med.v5i2.354

Nofiani, R. \& Ardiningsih, P. 2018. Physicochemical and Microbiological Profil of Commercial Cincalok from West Kalimantan. Jurnal Pengolahan Hasil Perikanan Indonesia. 21(2):243-249. doi: 10.17844/jphpi.v21i2.22851

Nugroho, A. 2017. Buku Ajar Teknologi Bahan Alam, Universitas Lambung Mangkurat, Banjarmasin.

Oh, S., Kim, Y.J., Lee, E.K., Park, S.W. \& Yu, H.G. 2020. Antioxidative Effects of Ascorbic
Acid and Astaxanthin on ARPE-19 Cells in an Oxidative Stress Model. Antioxidants 9(833):1-15. doi: 10.3390/antiox9090833

Pham-Huy, L.A., He, H. \& Pham-Huy, C. 2008. Free Radicals, Antioxidants in Disease and Health, International Journal of Biomedical Science. 4(2): 89-96.

Rinto, 2018. Manfaat Fungsional Produk Fermentasi Hasil Perikanan Indonesia, UPT. Universitas Sriwijaya, Palembang.

Rodriguez, D.B. 2001. A Guide to Carotenoid Analysis in Food, ILSI Press, Washington.

Rohimat, Widowati, I. \& Trianto, A. 2014. Aktivitas Antioksidan Ekstrak Metanol Rumput Laut Coklat (Turbinaria conoides dan Sargassum cristaefolium) yang Dikoleksi dari Pantai Rancabuaya Garut Jawa Barat. Journal of Marine Research. 3(3):304-313

Senthamil, L. \& Kumaresan, R. 2015. Extraction and Identification of Astaxanthin from Shrimp Waste. Indian Journal of Research in Pharmacy and Biotechnology. 3(3): 192-195.

Silva, F.O.D., Tramonte, V.L.C., Parisenti, J., Lima-Garcia, J.F., Maraschin, M. \& Silva, E. L.D. 2015. Litopenaeus Vannamei, Muscle Carotenoids Versus, Astaxanthin: A Comparison of Antioxidant Activity and in Vitro, Protective Effect Against Lipid Peroxidation. Food Bioscience. 9:12-19. doi: 10.1016/j.fbio.2014.11.001

Sudarmadji, S., Haryono, B., \& Suhardi. 1997. Prosedur Analisis untuk Bahan Makanan dan Pertanian, Liberty, Yogyakarta.

Suhartati, T. 2017. Dasar-Dasar Spektrofotometri UV-Vis dan Spektrometri Massa untuk Penentuan Struktur Senyawa Organik, AURA, Bandar Lampung.

Torrisen, O.J., Tidemann, E., Hansen, F. \& Raa, J. 1981. Ensiling in Acid a Method to Stabilize Astaxanthin in Shrimp Processing by-Products and Improve Uptake of this Pigment by Rainbow Trout (Salmo Gairdneri), Aquaculture. 26: 77-83. doi: 10.1016/0044-8486(81)90111-3

Wahyuningsih, K.A. 2011. Astaxanthin Memberikan Efek Proteksi terhadap Photoaging. Damianus Journal of Medicine. 10(3): 149-160.

Wulandari, I. 2011. Kromatografi Lapis Tipis, Taman Kampus Presindo, Jember. 
Zahrah, Z., Amin, M.N.G. \& Alamsjah, M.A. 2020. The Effect of Fucoxanthun as Coloring Agent on the Quality of Shrimp
Paste, IOP Conference Series: Earth and Environmental Science. 441:012079. doi: 10.1088/1755-1315/441/1/012079 